\title{
Space, state-building and the hydraulic mission: crafting the Mozambican State
}

Article

Accepted Version

Rusca, M., dos Santos, T., Menga, F., Mirumachi, N., Schwartz, K. and Hordijk, M. (2019) Space, state-building and the hydraulic mission: crafting the Mozambican State.

Environment and Planning C: Politics and Space, 37 (5). pp. 868-888. ISSN 2399-6544 doi: https://doi.org/10.1177/0263774X18812171 Available at https://centaur.reading.ac.uk/80773/

It is advisable to refer to the publisher's version if you intend to cite from the work. See Guidance on citing.

To link to this article DOI: http://dx.doi.org/10.1177/0263774X18812171

Publisher: SAGE

All outputs in CentAUR are protected by Intellectual Property Rights law, including copyright law. Copyright and IPR is retained by the creators or other copyright holders. Terms and conditions for use of this material are defined in the End User Agreement.

\section{www.reading.ac.uk/centaur}

\section{CentAUR}


Central Archive at the University of Reading

Reading's research outputs online 


\title{
Space, state-building and the hydraulic mission: Crafting the Mozambican State
}

\author{
Rusca, Maria $^{a b^{*}}$; dos Santos, Tatiana ${ }^{\mathrm{c}}$; Menga, Filippo ${ }^{\mathrm{d}}$; Mirumachi, Naho ${ }^{\mathrm{e}}$; Schwartz, Klaas ; \\ Hordijk, Michaela ${ }^{\mathrm{g}}$
}

${ }^{a}$ Uppsala University, Department of Earth Sciences, Villavägen 16, 75236 Uppsala, Sweden maria.rusca@geo.uu.se *; ${ }^{b}$ Centre of Natural Hazards and Disaster Science, 75236 Uppsala, Sweden; 'Independent Researcher, tatiana.silva@maisfavela.org; ${ }^{\mathrm{d}}$ University of Reading, Department of Geography and Environmental Science, Russell Building, Reading, RG6 6AB, UK, f.menga@ reading.ac.uk; ${ }^{\mathrm{e}}$ King's College London, Department of Geography, Bush House North East Wing, London WC2B 4BG UK, naho.mirumachi@kcl.ac.uk; ${ }^{\mathrm{f}}$ IHE Delft Institute for Water Education, Department of Integrated Water Systems and Governance, Westvest 7, 2611AX Delft, The Netherlands and Amsterdam Institute for Social Science Research, University of Amsterdam, $1001 \mathrm{NC}$

Amsterdam, the Netherlands k.schwartz@un-ihe.org ; ${ }^{\mathrm{g}}$ Amsterdam Institute for Social Science Research, University of Amsterdam, 1001 NC Amsterdam, the Netherlands, and Institute for Water Education, IHE Delft Institute for Water Education, Westvest 7, 2611AX Delft, the Netherlands, m.a.hordijk@uva.nl.

* Corresponding Author: Maria Rusca, maria.rusca@gmail.com

This is an Accepted Manuscript of an article published by SAGE Journals in Environment and Planning C.

\begin{abstract}
This article explores the role of large-scale water infrastructure in the formation of states in subSaharan Africa. We examine this through a focus on government agents and their shifting hydrodevelopmental visions of the state in colonial and post-colonial Mozambique. Over time, the focus, underlying principles, and goals of the hydraulic mission shifted, triggered by contextual factors and historical developments within and outside the country. We identify the making of three hydraulic paradigms, fostering different imaginaries of 'the state' and social and spatial engineering of the territory: the 'Estado Novo' (1930 - 1974), the socialist post-independence state-space (1974 - 1987) and the neoliberal state (1987 - present). We then conclude by discussing how the shifting discursive justifications for infrastructure projects consolidate different state projects and link these to material re-patterning of hydrosocial territories, showing that whilst promoted as a rupture with the past, emerging projects tend to reaffirm, rather than redistribute, power and water within the country.
\end{abstract}

\section{Key words}

State, space, hydro-developmental visions, agro-industrial development, urban water supply. 
"What happens is that this country is under construction; it is superficial. The colonial powers arrived, divided Africa and created a country named Mozambique. It is artificial [...] we invented the nation with parachutes and now we are trying to create the social, economic, institutional and cultural organic fabric that does not exist" (Former high-level officer of the National Directorate of Water-DNA, 2013).

\section{Introduction}

Despite the high costs and their often low return in terms of benefits, dams continue to be promoted as a means to increase welfare by ensuring flood protection, expanding supplies of potable water, enhancing water security, and by augmenting food and energy production (Kirchherr, 2018; Merme et al., 2014; Molle et al., 2009). In 2000, the World Commission on Dams (WCD, 2000) released a report that provided good practice guidelines to planners and decision-makers about the social and environmental inequalities triggered by large dams. These inequalities had been increasingly seen as problematic and tempered the growth of the dam business. And yet, a rise in water and energy demands, the increased price of carbon fuels, climate change and the need to produce more renewable energy have led to a resurgence of large hydropower developments globally (Crow-Miller et al., 2017; Moore et al., 2010).

Scholars have linked the discursive justifications of large hydraulic infrastructure with their materiality, illustrating how dams can become a central tool in the deployment of a social and spatial engineering strategy aimed at ordering water flows, space and population worldwide (Meehan, 2014; Molle et al. 2009; Wester et al., 2009; Kaika, 2006). As Meehan (2014: 215) noted, "infrastructure itself plays a role in cultivating or delimiting state power", defining the state's spatiality and demonstrating control over the territory on which large water infrastructures are constructed and produce their impacts (Kaika, 2006; Linton, 2010; McCully, 1996; Scott, 1999).

In the next section, we engage in a brief conceptual discussion on state-building, space and the hydraulic mission, to delineate how the state can be interpreted as a conceptual abstraction that is actualised through large infrastructure. We build on this literature by looking at the politics of large-scale water infrastructure development in Mozambique. By doing so, we shed light on the relationship between space, state-building and authority - particularly centralised authority. The centralised authority of Mozambique presents powerful measures to delineate the spatiality of space all whilst evolving.

Two intertwined themes run through this paper and contribute to conceptualise the relation between hydraulic infrastructure and the construction of state-space. The first concerns the development of hydraulic infrastructures as a technique for consolidation of different state imaginaries (Boelens et al., 2016; Meehan, 2014). Here our analysis focuses on different state imaginaries, discourses, and justifications for infrastructure projects and how these consolidate different understandings of the state as an abstract domain. Drawing on Mitchell's (2006) work 
on the 'state as an effect' (see also Bridge, 2013; Harris and Alatout, 2010; Robbins, 2008), we argue that shifting hydro-developmental visions of the state have been central to the construction of evolving nation-state(s) imaginaries. The second theme concerns material re-patterning of socionatural relations produced by the 'state as an effect' (Menga and Swyngedouw, 2018; Bridge, 2013; Harris, 2012; Neuman, 1996). This material re-patterning, translate in hydrosocial territories symbolising "processes of inclusion and exclusion, development and marginalization" (Boelens et al., 2016: 2). Both themes require a close analysis of the way government agents operate, materially and discursively, demonstrating political power. We show how subsequent hydro-developmental visions of the state, often promoted as a rupture with the past, in fact result in socio-environmental configurations that reiterate rather than reduce uneven development in the country. Characteristic of this uneven development is that stakeholders whose interests are closely linked to those of the elite benefit most from hydraulic infrastructure development in the country.

The case study is based on data collected through ethnographic fieldwork in Mozambique between November 2013 and February 2014. 47 semi-structured interviews were conducted with planners, civil engineers, government representatives, donors, international lending agencies, sugar industry and consultants. In addition, archival research was undertaken at the National Directorate of Water (DNA) and the Ministry of Public Works and Housing. The analysis of archival documents includes 10 World Bank project documents and consultancy reports from both colonial and postcolonial times. Historical maps were used to visualise state territory and the changing socio-ecological configurations, and as an object of analysis (Foster, 2013).

\title{
State-building, space and the hydraulic mission
}

\begin{abstract}
"What, then, is the state? According to the 'politicologists', it is a framework that of a power which makes decisions in such a way as to ensure that the interests of certain minorities, of certain classes or fractions of classes, are imposed on society - so effectively imposed, in fact, that they become indistinguishable from the general interest. Fair enough, but we must not forget that the framework in question is a spatial one" (Lefebvre, 1991: 281).
\end{abstract}

We define space and the state as dynamic entities, which are actively and continuously produced through interpretive and material practices (Mitchell, 2006; Shapiro, 2003; Radcliffe, 2001; Lefebvre, 1991). The state emerges as an "abstract domain of collective coherence and attachment" (Shapiro, 2003: 272), and is constructed and reified through discourses, infrastructure, monuments, maps and other practices (Eriksen, 2002; Radcliffe, 2001). The spaces produced are the ones over which the state is made sense of: the territory (Brenner and Elden, 2009; Lefebvre, 1991). While the state is not monolithic, government agents can be seen to actively work to sustain, consolidate and perpetuate practices. In line with the argument 
advanced by Fantini et al. (2018: 66), state territorialisation emerges as "the discursive and material production of the state's territory through the restructuring of the biophysical space", which allows the state to increase its resource accumulation capacity.

While the nation tends to be conceived as an abstract entity revolving around ideologies and shared imaginations (Eriksen, 2002; Anderson, 1991), the state is often portrayed as a fixed, homogenous and almost tangible administrative entity. However, the state embodies more complex meanings (Abrams 1988), and, as the nation, it can also be conceptualised as an imagined entity (Radcliffe, 2001), one that is socially constructed and co-constituted out of its material and ideological capabilities (Menga and Swyngedouw, 2018). Social relations of stateness permeate everyday life in mundane and prosaic ways (Painter, 2006), and as Mitchell (2006: 170) argues, "the phenomenon we name 'the State' arises from techniques that enable mundane material practices to take on the appearance of an abstract, non-material form". These material practices include, for instance, military uniforms, infrastructures (public buildings, roads, dams, networks) that enable the ordering and the control of people, production of goods (Rodgers and O'Neill, 2012; Scott, 1999) and laws (Meehan, 2014). The abstract state is, thus, a unifying rationality representing all the practices that ultimately work for the creation and reification of the non-material forms of the state, including the provision of public services such as water supply (Bakker, 2010). As such, the idea of state "has considerable political reality" in which the states function as a socially constructed "device in terms of which subjection is legitimated" (Abrams, 1988: 68).

As suggested in the quotation above, for Lefebvre (1991: 280) "sovereignty implies space" and the ordering and control of people, laws and the production of goods are linked to a particular unifying rationality embodying spatiality. The set of material and social practices constructing the state produces the spatial dimension where the power of this imagined entity is experienced as valid and legitimate. Revisiting Lefebvre's writings ${ }^{1}$, Brenner and Elden (2009: 363) elaborate on the definition of territory as a "historically specific political form of (produced) space territorial space [...] comprehensible only through its relation to the state and process of statecraft". What is called the territory of the state is the state-space produced through ordering, controlling and regulating in accordance with the state project of the actors in rule (Brenner and Elden, 2009; Brenner et al, 2003; Lefebvre, 1991).

Large water infrastructures, like dams, are observable representations of the modern state imaginary and a powerful means of production and reification of state-space (Boelens et al., 2016; Kaika, 2006). Over history, these 'temples of modernity' emerge as prime examples of high-modernism and symbolise the state's dominance over flows of water and the space in which they unravel (Linton, 2010; Scott, 1999). Recent studies convincingly explain how the development of water infrastructure contributes to the production of state-space by regulating and controlling previously unregulated water flows (Linton and Delay, 2018; Harris 2012; Harris

\footnotetext{
${ }^{1}$ The arguments are drawn upon Lefebvre's The Production of Space (1991 [1974]); The Survival of Capitalism: Reproduction of the Relation of Production (1976) and De L'État (1976-1978).
} 
and Alatout, 2010). Often materialised in dam projects and irrigation schemes, the hydraulic mission changes the natural landscape, enabling the capture, access and allocation of water (Allan, 2003; Swyngedouw, 2004). The construction of dams has also become a common practice through which bureaucrats legitimate and consolidate their grip on power (Atkins, 2018; Menga, 2015). Centralised authorities are effective in this regard as they are able to command the distribution of water in a top-down fashion: a certain clique of elite decision-makers or the hydraulic bureaucracy work to determine how and when water is allocated (Mirumachi, 2015). Large water infrastructure can thus be seen as a tool that helps entrench bureaucratic control in both despotic and democratic regimes (Meehan, 2014; Wittfogel, 1957).

With the above in mind, the state appears as a dynamic and evolving arrangement that is continuously negotiated, and thus inevitably also contested, by a wide array of users and interest groups. Government actors, keen to sustain power, need to counter and rebuff such contestations. In this regard, a historical perspective furthers our understanding of how different hydraulic paradigms can be mobilised by those in power to promote different imaginaries of the state. In the upcoming analysis, we will explore the role of large-scale water infrastructure in forming and restructuring the Mozambican state between 1926 and 2015, illustrating the deep interrelation between various state visions towards hydraulic infrastructure, imaginaries of the state, and the re-patterning of socio-ecological configurations in the country.

\title{
The hydro-developmental visions of the Mozambican state
}

\begin{abstract}
"One of the fundamental characteristics of Mozambique is the problem of water management. Mozambique is a very dry country that always faces a contradiction: it has a lot of water or none. During the dry period, people do not have water. Every January to March, people are always struggling with floods. Water management is something we must deal with as soon as we step out of the door. It is a daily discussion; we do not understand why we have so much water but none in our taps and houses. Something else we always face is the high dependence of international water resources [...] there is this issue that even the little water that runs to our country, we cannot control" (FIPAG, 2014, personal communication).
\end{abstract}

The above statement of a former high-level official of the water asset holding company FIPAG fosters a common and persistent discourse, instrumental in the promotion of large water infrastructure in Mozambique and elsewhere: water is both scarce and abundant, and the dependency on international rivers exacerbates insecurity and poses obstacles to national development. The necessity to tame rivers and limit natural fluctuations in the water flow is a recurrent justification that planners and decision-makers use to advance their hydraulic ambitions (see among others Mitchell, 2002; Worster, 1985). This is also evident in Mozambique, where agriculture is part of daily life, its geographic position makes it vulnerable in terms of access to quantity and quality of water, and water service provisioning in the country is far from universal, 
large water infrastructures play a crucial role in the construction of the Mozambican states projects.

In colonial times the dominant discourses around dams underlined their undisputed positive impacts on agricultural development and, to a lesser extent, communications and transport for European settlers, as well as to "foster human progress through an improved standard of living for thousands of Africans who live and work there". ${ }^{2}$ Similarly, post-colonial development narratives reified the need for the 'temples of modernity' to deliver the modern Mozambican State. The surroundings of Mozambique's capital - Maputo - benefitted from a development program that "takes as fundamental natural resources water and land for the development of modern agriculture and deployment of industries out of urban centres and serving as a driver for rural development in collective forms of production and social organization" (DNA, 1980). In this development narrative, land, water, modernity and social order are inextricably linked and large water infrastructure plays a unifying role. This view is supported by studies undertaken by the colonial state, classifying the region as holding "natural conditions that favour rapid agricultural development (fertile soils and water availability)", but subject to "irregular rainfall" (DNA, 1980).

Development through large infrastructure remains central to the agenda of the contemporary Mozambican State, aligned with global narratives of water security for growing urban populations, and multiple and integrated uses.

We are even late because when we look at countries like South Africa, which have a very high economic and financial capacity, they have a lot of dams. In terms of water security, they are much better than us. Mozambique, due to its position, cannot be held hostage to nature. When there are floods, there are floods, when there is drought, there is drought [...]. Those dams are necessary [...] It is not possible to develop the country without some sort of water security (Former high-level authority FIPAG, 2013, personal communication).

The discourse around the transformative power of large infrastructure is a clear element of continuity between colonial and post-colonial governments and their state-space imaginaries. The focus of the hydraulic mission has, however, shifted over time because of contextual factors and historical developments within and outside Mozambique. As shown below, the shifting imaginaries served to consolidate different bureaucratic powers against external powers and domestic groups at various moments, representing a dynamic and evolving state.

\section{The production of the empire state-space: the Estado Novo}

The hydro-developmental vision of the empire state, developed as part of the Portuguese 'Estado Novo' (1930-1974), served to consolidate an imaginary of the state grounded on principles of racial superiority and a segregationist spatial order. The Portuguese state project was slow-

\footnotetext{
${ }^{2}$ Portugal, Secretario de Estado da Informacao e Turismo, Cahora Bassa on the move (Lisbon: Agencia Geral do Ultramar, n.d.), p. 21 in Isaacman and Isaacman (2013).
} 
moving, complex and largely driven by external forces. In the $19^{\text {th }}$ century, after more than three centuries of modest presence in the Mozambican territories, European colonial powers pressured Portugal into taking a more significant role in the country (Macagno, 2009; Sidaway, 1993). Emblematic is the 1884-1885 Berlin conference, where European States criticised Portugal for the weak and unregulated occupation of the territory and for the low productivity of the concession companies (Sabaratnam, 2013). Portugal did not have the human and financial capacity to control the vast spaces of the colonial territory and opted for increasing its presence in Maputo Bay, outlet of the three main rivers crossing the southern plains: the Incomati, the Umbeluzi and the Maputo (Hall and Young, 1997). The empire state project largely focused on development of the capital Lourenço Marques and its hinterland. Large water infrastructures were at the centre of this project and intersected with the racial policies governing the colony. The Portuguese authoritarian regime, 'Estado Novo' $(1930$ - 1974), emanated the Colonial Act (1930) and the Organic Charter (1933) which established a clear division between the citizens (i.e. colonial elites) and the indigenous population (Barros et al., 2014; Sabaratnam, 2013). In the city, this translated into a spatial organisation of the population, grounded on "distinctly racial lines, with the majority of African residents living outside the planned urban area" (Jenkins, 2000: 208), reiterated through the development of hydraulic infrastructure. The colonial government introduced a public and centralised water supply system. This system was typical of hydraulic mission projects with a high modernist ideal but only to facilitate the exclusive water supply of the Portuguese population and the indigenous elites (former high-level DNA official, 2013, personal communication). As the majority of the indigenous population was pushed to the outskirts of the city, subject to a distinct and poorly financed administrative system, exclusivity of water supply was easily achieved by concentrating the network in the so-called 'cement city' (Ahlers et al., 2013; Jenkins, 2000). Moreover, water was abstracted from the Umbeluzi River, through an intake constructed in 1930 in an area historically used by the locals as water source (former high-level DNA official, 2013, personal communication; MOPH/FIPAG, 2011).

The strategy for hydropower and irrigation development envisaged the construction of four dams - Corumana, Moamba Major, Movene and Chualí - at the outskirts of Lourenço Marques (Ataíde, 1970; Província Ultramarina de Moçambique, 1948-1949). This project, however, was held off due to the start of the liberation struggle. Mozambican elites (so-called assimilados) opposed the segregation system and the Mozambican Liberation Front (FRELIMO), founded in 1962, led the struggle that progressively freed northern Mozambique (1964-1975), where the presence of the empire state was marginal (Pitcher, 2006; Hall and Young, 1997; Simpson, 1993; Sidaway, 1992). In response to this threat, the colonial government prioritised the construction and protection of Cahora Bassa dam, located in the northern part of the country on the Zambezi River. The dam served as a coercive form of social-spatial engineering, used as military 'weapon' to prevent the expansion of FRELIMO's control to the south (Hall and Young, 1997). In turn, the

\footnotetext{
${ }^{3}$ This refers to the permanent cidade cimento built for settlers, as juxtaposed to the reed city, cidade caniço, which refers to the temporary houses that were built in the outskirts of the city.
} 
dam became a military and political target for the rebels: "The agenda of Frelimo in Tete is: Cahora Bassa delenda est - Cahora Bassa must be destroyed!"4

The dam, promoted by authorities to foster national economic growth, mainly served to reinforce the diplomatic relationship with the apartheid regime in South Africa. While rural Mozambicans paid the price of relocation and loss of livelihood and land, most of the energy produced by Cahora Bassa was sold at a cheap price to South Africa through a complex system of pylons stretching for over 1800 kilometres and (Isaacman and Isaacman, 2013). FRELIMO saw Cahora Bassa dam as an antagonising symbol of the empire state, supported by "big financial interests and reactionary political forces", 5 attempting to justify the project by positioning the dam as an opportunity for Mozambican people:

"They argue that the building of the dam will give work to thousands of Mozambicans both in the building and the resulting industrial complex. That it will irrigate thousands of hectares of land, thus allowing hundreds of thousands of people to benefit from this arable land. That this would attract foreign investments. Thus, facilitating the development of the country. That it will make the Zambesi navigable up to the Indian Ocean. And that, since independence will come sooner or later, it is advisable to let the dam be built: because an independent Mozambique will be in a much better economic situation with the dam than without it."

For FRELIMO, Mozambicans were virtually subject to "a system of forced labour"7, which frustrated any work opportunity coming from the construction of the dam. Similarly, it was clear to FRELIMO that the new arable land would not benefit Mozambicans, "but rather white settlers immigrating from Portugal, South Africa, Rhodesia and Western Europe." 8 The position of the postcolonial government on Cahora Bassa, however, soon changed to align with colonial discourses on the transformative power of the dam for economic development, in the attempt "to turn an exploitative colonial project into a national asset" (Power and Kirshner, 2018: 6).

\section{The production of the welfare state-space: hydraulic bureaucracies and irrigation development}

The post-independence welfare state (1974 - 1987) sought legitimation under the flagship of egalitarianism and inclusive development, in which water resources and large infrastructures were to play a prominent role. Narratives and discourses of state actors mainly focused on land

\footnotetext{
${ }^{4}$ Voz da Revolução 9 (1968) Mensagem do Ano Novo de Eduardo Mondlane (New Year's message from Eduardo Mondlane). Available at: http://casacomum.org/cc/visualizador?pasta=04331.006.010\#!2

5 (1970-1970), "Cahora Bassa. Why we say no", CasaComum.org, Disponível HTTP: http://hdl.handle.net/11002/fms_dc_161789 (2018-4-18), Instituição: Fundação Mário Soares Pasta: 05787.020.

6 Ibid.

7 Ibid.

8 Ibid.
} 
and water resources for irrigation and electrification for all. Following the coup d'état that ended the Estado Novo in Portugal (1974), FRELIMO self-declared itself as the only legitimate political authority and proclaimed central planning under a Marxist-Leninist programme (Macagno, 2009; Sumich, 2010; Sidaway, 1993). The second Mozambican state-building project worked to "push the territory and population along a socialist developmental pathway away from colonialism" (Sabaratnam, 2013: 112). This was mainly done through the reorganisation of the territory and the promotion of 'egalitarian' development. Water resources and infrastructures played a central role in both: the reorganisation of the territory entailed nationalisation of land and water resources, and rural territories became cooperatives, named aldeias communais (Friedman, 1980). FRELIMO maintained the idea that large hydropower dams were essential to foster national economic development:

"We cannot irrigate without energy. The electrification of the central area of the North
and of the South of our country is fundamental for us to be able to meet the needs of
agriculture [...]. Within the next decade the north bank power station [at Cahora Bassa]
must begin functioning and numerous dams must be built for irrigation and
electrification".9

Paradoxically, the production of the Mozambican 'egalitarian' state project was advanced by resuming the Portuguese plans for water resources development. First, Southern Mozambique was identified as the most suitable area for large water infrastructure developments. Secondly, the newly established Directorate for Water (DNA) revived the colonial state's project of a development pole in southern Mozambique. Central to this project was the establishment of government-controlled agro-industrial units and cooperatives to run the state farms, under four hydro-agriculture schemes (see Figure 1). To this aim, the new state also envisioned the implementation of another plan inherited by the colonial state: the construction of four dams on the Incomati river "to control water flows and [...] for the development of intensive agriculture" (DNA, 1980). The agro-industrial units, therefore, were to be supplied with water by the combined operation of the Corumana, Moamba Major, Movene, Chualí and Pequenos Libombos dams, which would enable the expansion of the irrigated lands and significantly augment agroindustrial production (DNA, 1980). By controlling the rivers and satisfying irrigation needs, these dams were to become symbols of the successful spur of agro-industrial development (DNA, 1980).

Water resources development became even more urgent because of the rapid growth of intense agriculture in South Africa, which held the privileged upstream position to over $50 \%$ of the waters crossing the southern Mozambican plains (Ataíde, 1970; Província Ultramarina de Moçambique, 1948-1949). The hydraulic infrastructures, therefore, also symbolised Mozambique's autonomy from neighbouring countries:

\footnotetext{
${ }^{9}$ AIM Information Bulletin 38 (1979): 6 in Isaacman and Isaacman (2013).
} 
"The water availability brings agricultural potential to Mozambique. [...] This would mean, in practice, that we would stop consuming food from South Africa" (Former high-level Mozambican government official, 2014, personal communication).

Part of the process of promoting large water infrastructure entailed re-thinking water governance structures in the country by establishing new responsibilities and apparatuses of water management within the Mozambican government. Technocrats such as water engineers, hydrologists and other members of the irrigation sector were given a prominent role in the government. The forced exodus of over 400,000 Portuguese drained the capacity in several sectors, including water resources and services management. As such, the emerging local hydraulic bureaucracy were offered new opportunities to rapidly progress and quickly rose to power by filling in managerial positons that suddenly became available:

"many services had been abandoned because they were managed by the Portuguese [...] Two years after I left university I was in charge of all the water and sanitation in Mozambique. We were learning while doing things" (Former high-level DNA official, 2013, personal communication).

Figure 1 - Hydraulic infrastructures and agro-industrial units planned on the Incomati.

Source: Map by Janet Said, based on DNA, 1980; World Bank 2013.

The construction of water infrastructure to materially represent and reify FRELIMO's Mozambican state project in the territory liberated from the Portuguese colonial rule only partially materialised. In 1982, the Italian bank Mediocredito disbursed a US\$ 13 billion loan to Banco de Moçambique for the construction of Corumana Dam and the construction contract was awarded to the consortium Co.bo.co (Condotte d'Acqua, Bonifica-IRI, Lega delle Cooperative) (Bussotti and De Muti, 2013). A second loan of US\$ 110 million concerned the construction of the smaller and cheaper Pequenos Libombos dam, awarded to another Italian Consortium, the Consorzio Strade-Italstrade and Calzoni Company, for which a second agreement was signed with Mediocredito (Bussotti and De Muti, 2013). However, these projects were truncated by the civil war (1977-92). Immediately after Frelimo's announcement of its Marxist-Leninist agenda in 1977, opposition arose from militants of the Mozambican National Resistance (RENAMO). During the war, part of the international funds acquired for the construction of the dams were diverted to cover military expenses (DNA official, 2013, personal communication). Construction sites, as many other symbols of the state including health and education centres, were attacked by RENAMO and required a guards and security:

Their goal [RENAMO's] was to make unviable a project that would strengthen the 
government [of FRELIMO], which would have a development pole. [...] In places like Corumana, closer to the border with South Africa, the guerrilla was more effective, because it was supported by the Apartheid regime. They would come here and attack, and when we would attack them, they would cross the border to South Africa. (DNA official, 2013, personal communication).

With RENAMO controlling large parts of the rural areas, FRELIMO focused on developing infrastructure in the cities, particularly the capital Maputo ${ }^{10}$, and in the 'corridors' connecting urban areas (Sidaway, 1993). Investments focused on the Pequenos Libombos (1986) and Corumana Dam (1989). The Pequenos Libombos, the main source of water for Maputo and agriculture, was constructed without its planned power generation plant (Bussotti and De Mutti, 2013). The Corumana dam (1989), the second large-scale water infrastructure constructed in this era, secured water for sugar cane production and export, albeit with limited capacity since it lacks the spillway gates that would have doubled its storage capacity (DNA official, 2013, personal communication).

\section{The neoliberal state-space: global market and the modern city}

Confronted with a rapid urbanization, the international development establishment increasingly directed its attention to the fast and informally growing cities in the developing world (see, for instance, UN-Habitat 2016). Concurrently, the onset of neoliberalism in the water sector lead to a set of reforms ranging from deregulation, establishment of property rights, privatization, marketization, and corporatization of water resources and services (Rusca and Schwartz, 2018; Bakker, 2007; Castree 2005). The emerging hydro-developmental vision of the Mozambican state and its urban 'modernization' imaginary (1987 - present) were directed towards reshaping the city in line with demands of market forces and modernity. This vision is strongly influenced by these global processes and is intrinsically linked to the increased reliance of Mozambique on international donors, following the devastating civil war and the subsequent economic crisis. However, while state agents' narratives and discourses mainly focus on urban modernization, a large part of the hydraulic bureaucracy still places emphasis on agriculture, in particular commercial agriculture which would drive agro-industrial economic development as the longterm goal.

In line with the World Bank and IMF prescriptions, Mozambique initiated a reform program, which signified a shift from a socialist system characterised by centralised planning, to a neoliberal one, with a greater reliance on market forces and the private sector. The structural adjustment programme adopted in 1987 under Chissano's presidency (1986 - 2005) is the most significant and holistic neoliberal reform adopted by the Mozambican government. The

\footnotetext{
${ }^{10}$ The capital city, named by the Portuguese after the explorer Lourenço Marques (1898), became Maputo as part of the postcolonial state building project.
} 
Economic and Social Rehabilitation Program (Programa de Reabilitação Económica e Social) aimed to "progressively reduce centralised administrative controls and encourage more private sector participation" (World Bank, 1987: 6). In the mid-90s, donors' influence extended to the water sector leading to several neoliberal reforms that contributed to the re-shaping of the new hydraulic mission. The Water Resources Development I (1998) and II (1999), and the National Water Policy (1995) called for a greater reliance on the private sector and for the introduction of commercial principles. Water service provision underwent a similar process: in 1998, the government emanated the Delegated Management Framework (DMF), which constitutes a 'coordinated set of organizations and legal mechanisms that allow the participation of private entities in the management of public water services' (Decree 72/98, art. 1c).

\begin{abstract}
"This influence doesn't mean that donors are 100\% decision-makers, but as financers they impose conditions. There is no investor who is willing to give money without any guarantee of payback [...] Sometimes we are of the opinion that a particular scenario would be better, but donors have a different view, and at a certain point their ideas will prevail [...] Many of these countries are not giving donations: they are making business. Their business is to sell the money, for which we have to pay interests." (FIPAG official, 2014, personal communication).
\end{abstract}

The stated goals of the water sector remained water resources development for poverty reduction and economic growth. Inadequate infrastructural development was, again, argued to be the "primary constraint to economic growth and development, improved service delivery and poverty reduction." (World Bank, 2011: 1). These plans, however, were affected by a global shift of the 1990s and 2000s towards a more reflexive approach to the trade-offs of dam construction and the prioritisation of 'soft' water management strategies (Allan, 2003; Ben-Crow et al., 2017).

"The financing of a dam became very complicated. A lot of money was needed to make Moamba Major and we did not have the financing conditions we had for Corumana. We had Civil War. The World Bank, as well as other donors, were not very excited. There was a trend of "freezing" the dams for environmental reasons. Then, for poor countries, it becomes very difficult to move on with projects for dams" (Former high-level DNA official, 2013, personal communication).

For the Mozambican government to get donors on board and finance dams, the hydraulic mission needed to be altered to reflect new priorities of the international community and financing agencies, which were increasingly concerned with urban waters. In line with the discursive requirements of donors, the Mozambican hydraulic bureaucracy adopted a new discourse, shifting from progress for all through agro-industrial economic development to a more integrated approach in which urban water supply figures more prominently. The new projects were thus promoted and rationalised as a means to increase bulk water availability for the city, and justified on the grounds that the Pequenos Libombos Dam had almost reached its full production capacity. 
A second way in which donors influenced Mozambique's hydraulic mission concerns the selection of the projects to be prioritised. The construction of Moamba Major, postponed during the civil war, was high on the government's agenda. Yet, the World Bank played a key role in shifting the priorities by disbursing US\$ 42 million to install the spill gates at Corumana Dam to almost double its storage capacity (World Bank, 2011). For the World Bank (2007: 3), this was the most cost-effective effective solution, "the necessary and immediate investment to be implemented as the first stage of increment supply to Maputo". The Corumana system was incorporated in the Maputo Water Supply Project (MWSP), reiterating its function of increasing water supply to the city (FIPAG official, 2014, personal communication). FIPAG supported this strategy and saw Corumana as the fastest solution to ensure water to Maputo, while Moamba Major Dam was still "a dream" (FIPAG official, 2014, personal communication).

Although the prioratisation of Corumana shows the central role played by donors in shaping the new hydraulic mission, their influence is not to be overestimated. Except for FIPAG, whose mandate - urban water supply - coincides with the emerging donors' orientation, the hydraulic bureaucracy saw compliance to the priorities set by the World Bank and other donors as temporary. For them, water supply was a "short-term goal" (DNA official (1), 2013, personal communication) or a "temporary" measure (DNA official (2), 2013, personal communication). For this large segment of the bureaucracy, agro-industrial economic development remains the long-term goal: "Corumana will actually function as a reserve in case of necessity, as it was already constructed. Its main purpose is to supply water for agriculture" (Water Regulatory Agency official, 2013, personal communication). Counting on the flexibility of water infrastructure, they see the purpose of the dam shifting over time:

"The only premise under which the World Bank would release funds for the completion of Corumana dam was saying that the additional water would supply Maputo City. It was a decision to sort of make a nice face to the Bank and for them to do something that is not out of what they have been announcing. Mozambique could complete Moamba fast and say no, we are not going to abstract water from Corumana Dam. It is a sovereignty country. And what the World Bank is going to do? Go there and take the gates?" (DNA official (3), 2013, personal communication).

While formally the emphasis is on drinking water, the vision for development in Southern Mozambique remains strongly anchored to the role dams can play for the Valley and commercial agriculture:

"The characteristics of the Incomati Valley offer a great potential to agriculture, which is important to produce food for the people. It also has potential for cattle. We have to ensure water for this development. The only way to have water reserves is by constructing those works" (DNA official (4), 2013, personal communication).

This vision intersects with a wider geopolitical project aimed at reducing the influence of and reliance on South Africa in terms of food security in the country. Similarly, several water sector 
actors are looking at Corumana as a way to overcome dependence on the import of energy from South Africa:

"This imported energy is fixed, but in any urbanisation, there are peaks of demands. This required additional energy is very expensive. [...] Mozambique pays high bills for this peak supply. As the dam [Corumana] does not have spill gates, it produces limited energy. [...] With the completion, the height for discharge is going to increase; so the dam can produce more efficiently, spending less water to produce the same quantity of energy" (DNA official (5), 2013, personal communication).

Representatives from Ara-Sul, the water agency responsible for water resources management in southern basins ${ }^{11}$ and the related infrastructures, share a similar vision. Highlighting the historical purpose of Corumana they see it as a temporary urban water supply source until Moamba Major is operational. Subsequently, Moamba Major Dam will become the "essential water source for domestic use" (Water Management Unit Ara-Sul, 2013, personal communication).

Moamba Major has undergone a similar discursive construction. The project is mostly promoted for its transformation potential for the capital and its citizens. In 2010, the vice Minister of Public Work and Housing Gabriel Muthisse announced that the government was looking for private funding for the construction of Moamba Major. According to the vice Minister, the importance of the dam will become more evident in the coming years, when the Limpopo Dam will reach its production capacity. ${ }^{12}$ Besides FIPAG, who sees the Moamba major as a drinking water project (Government officials within FIPAG, 2014, personal communication), different government organisations see its potential beyond domestic water supply. The dam is seen as a way to support the expansion of the aluminium smelter MOZAL, the biggest industry in Mozambique, and of the Maputo Iron and Steel Project (DNA, 2012; Government official within DNA, 2013, personal communication). In addition, the dam is seen as providing a much needed resource to increase the irrigation area for sugarcane by 30,000 hectares, for which the sugar industry and commercial farmers have been waiting since the early 1990's (Sugar industry representative, 2014, personal communication): "there is a market. Sugarcane is going to be the main user on the medium term but irrigation is also going to be provided to other crops" (Water Management Unit Ara-Sul, 2013, personal communication; see Figure 1). Organisations highlighting the irrigation potential of Corumana and Moamba Major, see these dams as interconnected and having multiple and interchangeable purposes that can be modified over time and that will produce a regional-wide, rather than city-wide, impact and configuration of State-Space. This imaginary, in which agricultural and large scale farming are more prominent, presents strong elements of continuity with the hydraulic mission of the post-colonial welfare state.

Despite these differences, Moamba Major, framed as a social enterprise to quench the thirst of

\footnotetext{
${ }^{11}$ Umbeluzi, Maputo, Incomati and Limpopo

12 Ibid.
} 
the city and approved in election time, has created a wide consensus. In 2010, the Cabinet Council included its construction in the five-year plan of the elected Government (2010-2014) and a department for Moamba Major was created in DNA. ${ }^{70}$ Four years later an agreement was signed for its financing. The Brazilian Development Bank (BNDES) would contribute US\$ 352 million (75\%) and the Government of Mozambique US\$ 114 million (25\%) from the estimated total of US\$ 466 million (Representative of Andre Gutierrez Group).

With the exception of the road being built by the Chinese, Moamba Major is going to be the main public work of the country with a high social component. [...] The Minister, director of DNA, ARA-SUL. Everybody wants to be with Moamba Major. [...] It is going to be a winner. We do not have any bureaucracy problem; access is direct [...] they are in a hurry more than us. They are also in electoral year, so they want the works to start soon (FIPAG Official, 2014, personal communication).

Both the completion of Corumana and the construction of Moamba Major are, however, still in progress. The transport main (i.e. large distribution pipe) from Coruamana to Machacva distribution centre is yet to be completed, while the construction of the treatment plant has not yet started. ${ }^{13}$ It is not surprising, given the hidden agenda of a large section of the local bureaucracy that, with only the spillway gates completed, the large farmers in southern Mozambique are currently the only beneficiaries of the project. The Corumana dam now provides extra water to the farmers selling to the internationally-owned and export-oriented sugar factories Xinavane and Maragra. Currently, therefore, the large farmers in southern Mozambique, whose interests are closely linked to those of the elite, are the only beneficiaries of the expansion project. The additional water allowed them to nearly double their production. Meanwhile, especially in the dry season, downstream users complain about upstream intakes:

Unfortunately, the river does not allow much control. They [the sugar factories] have access to the river, they have their pumps. They go and take to the detriment of downstream users, who are the ones calling us to complain. If they complain and it is because someone in between is using more than it should, there is nothing we can do but to release more water (High level authority in ARA-SUL, 2014, personal communication).

Figure 2 - The Greater Maputo water supply expansion projects.

Source: Map developed by Janet Said, based on World Bank 2013.

\footnotetext{
13 Noticias on-line, Ligando Corumana ao Centro Distribuidor da Machava: Nova conduta de água vai aliviar Grande Maputo, 28 February 2018, accessed on April 23 at http://www.jornalnoticias.co.mz/index.php/capital/76292-ligando-corumana-ao-centro-distribuidor-da-machavanova-conduta-de-agua-vai-aliviar-grande-maputo.html
} 
The construction of Moamba Major has undergone several interruptions and re-negotiations. On February 8, 2018 Messias Macie, National Director of Water Resources Management indicated that the discontinuation of the project, started in 2014, was to be attributed to the lack of funds of the Mozambican government to cover its share of the costs. ${ }^{14}$ The country is now looking at possible donors to finance the completion of the works. It is difficult to predict when the dam will be operational and, meanwhile, nearly $50 \%$ of the population in the capital remain disconnected from the formal utility and rely on more than 800 small-scale providers for their drinking water supply (FIPAG staff, 2014, personal communication; MOPH/FIPAG, 2011). Over the past decade, the discourses and rationalisations for the construction of Corumana and Moamba Major shifted from agricultural development to water supply. In the practice, however, the urban water supply discourse, which gained traction in the neoliberal State project, did not materialise in the peripheries of the city, where the utility seems to be unable or unwilling to provide services (see also Rusca, 2018).

\section{Conclusions}

In this paper, we have traced the shifting hydro-developmental visions of Mozambique's state agents from the colonial era until present day. In doing so, the paper contributes to conceptualise the relation between hydraulic infrastructure and the production of state-space in three ways. First, we show how discursive justifications of water infrastructure development by government agents serve to solidify abstract imaginaries of the state, which dynamically evolve across various eras and regimes. Over time hydraulic infrastructures, whether celebrated, contested, reimagined, planned or implemented, were mobilised to promote a symbolic and material expression of a given state imaginary. These state imaginaries, grounded on principles that have shifted from superiority and dominance, to egalitarianism, modernity and neoliberalism, also have material implications for territorial and social order. In line with what Scott (1999) describes as the ordering of nature and society, (some) hydro-developmental visions materialise in different forms of territorialisation and spatial engineering of the population. The presence of the state is thus performed through both the abstract hydro-developmental visions and the resulting spatiality of water infrastructures, concentrated in some and absent in other areas, and stretching to territories in which water flows were previously unregulated.

Secondly, the discussion of the different state imaginaries in Mozambique highlights that their construction is subject to a variety of internal and external drivers. Major changes from colonial to post-colonial regimes impacted the kinds of state projects pursued. Global developments such as the onset of neoliberalism or concerns about environmental impact of dams, changing political regimes and development discourses all influence the construction of particular state projects. Following Painter and Jeffrey (2009), we thus, argue that emphasis should be placed on conceptualising the processes of gradual transformations of the state, paying attention to the role

\footnotetext{
14 The "Lava Jacto" corruption scandal in Brazil also involved Andrade Gutierrez, contractor on this project.
} 
played by historical and geographical shifts. Such an analysis also allows capturing the shifts and continuities between water-infrastructure and state-space linkages. Three interlinked elements of continuity between the colonial and the post-colonial state imaginaries can be highlighted in this respect. Like many other state-building ventures, in Mozambique there is a constant obsession with large-scale hydraulic infrastructures and the emphasis on their transformative power. Big change would appear to require big infrastructure. Large scale infrastructures once associated with the oppressor and contested by FRELIMO during the liberation struggle, became symbols of progress and development once the party was in power. Secondly, the hydraulic missions supporting the different state imaginaries have relied largely on technocratic expertise, emphasising the role of engineering and technology to control nature and to address socioeconomic problems in the country. States 'borrow' the legitimacy of technical and scientific progress (Scott, 1999) when promoting projects like the mastering of waters through dam development and other large infrastructures. This system contributed to reinforce existing hierarchies, and facilitated the concentration of power in the hands of a small number of development experts and the political elite. Thirdly, a commonality exists in the discord between the transformative intensions of state-building projects and associated large infrastructure as highlighted in policy documents and plans, and the ultimate beneficiaries. Whether lead by colonial elites or FRELIMO - with and without the influence of global markets forces and of international donor agencies -, the material re-patterning resulting from these state-building attempts have rarely benefitted the masses.

Last, the gradual transformation of the state is underpinned by various state agents working with and competing against discourses and narratives that make up conceptual abstractions of the Mozambican state. Rather than homogeneous and monolithic, the state as an abstraction is, thus, the result of the consolidation of one of many state imaginaries and hydro-development vision. At the core of this highly contested political process are the different and at times competing missions and visions of state agencies dealing with water resources and services management. This was particularly evident in the neoliberal state project where the role of actors beyond the state, especially donors and global market forces, is central to this process of consolidation. Although shifting hydro-developmental visions are a result of 'governance beyond the state', the recognition of flexibility of large infrastructure suggest that donors' influence is not necessarily permanent. Paradoxically to the concrete nature of infrastructure, state agents see large infrastructure projects as flexible and malleable: the purpose of dams can change over time and so can the hydro-developmental vision associated to it. Whilst outside the scope of this paper, we suggest this might stimulate new research directions and fruitful collaborations with scholarship inspired by Science and Technology Studies, which invites us to focus on infrastructure 'at use' and sees large technological systems as constantly evolving under the influence of contextual factors, and the interaction with the engineers and other actors operating and maintaining them (Tiwale et al., 2018; Shove, 2015; Furlong, 2015). 
Funding Acknowledgments: This project has received funding from the European Union's Horizon 2020 research and innovation programme under the Marie Skłodowska-Curie grant agreement INHAbIT Cities, No 656738 and UNHIDE sponsored by the Netherlands Ministry of Development Cooperation (DGIS) through the UNESCO-IHE Partnership Research Fund.

\section{References}

Abrams P (1988). Notes on the Difficulty of Studying the State. Journal of historical sociology, 1(1), pp.58-89.

Ahlers R, Guida VP, Rusca M and Schwartz K (2013) Unleashing Entrepreneurs or Controlling Unruly Providers? The Formalisation of Smallscale Water Providers in Greater Maputo, Mozambique. Journal of Development Studies 49(4): 470-482.

Allan T (2003) IWRM/IWRAM: a new sanctioned discourse? SOAS/KCL Occasional Paper 50 SOAS Water Issues Study Group School of Oriental and African Studies/King's College London University of London, UK.

Anderson B (1991) Imagined Communities: Reflections on the Origin and Spread of Nationalism. New York: Verso.

Ataíde C (1970) Vale di Incomáti: Esquematização geral dos Aproveitamentos hidráulicos. Report Direcção dos Serviços Hidraúlicos, Lourenço Marques, Mozambique.

Atkins E (2018) Building a dam, constructing a nation: The 'drowning'of Capel Celyn. Journal of Historical Sociology. Epub ahead of print 26 February 2018. doi.org/10.1111/johs. 12186.

Bakker, K. (2007). The commons versus the commodity: 'Alter'-globalization, privatization, and the human right to water in the global South. Antipode, 39(3), 430-455.

Bakker K (2010) Privatizing Water: Governance failure and the world's urban water crisis. Cornell: Cornell University Press.

Barros C, Chivangue A and Samagaio A (2014) Urban dynamics in Maputo, Mozambique. Cities 36: 74-82.

Boelens R, Hoogesteger J, Swyngedouw E, Vos J and Wester P (2016) Hydrosocial territories: a political ecology perspective, Water International, 41(1): 1-14.

Bogdandy A, Haubler S, Hanschmann F and Utz R (2005) State-building, nation-building, and constitutional politics in post-conflict situations: Conceptual clarifications and an appraisal of different approaches. Max Planck Yearbook of United Nations Law 9: 579613.

Bowen ML (2000) The State against the peasantry: rural struggles in colonial and post-colonial Mozambique. Charlottesville: University of Virginia Press.

Brenner N and Elden S (2009) Henry Lefebvre on state, space, territory. International Political Sociology 3: $353-377$.

Brenner N, Jessop B, Jones M and MacLeod G (2003) State/Space: a Reader. Oxford: Blackwell Publishing. 
Bridge G (2013) Resource geographies II: The resource-state nexus. Progress in Human Geography 38(1): 118-130.

Bussotti L and De Mutti A (2013) Italy and Mozambique: science, economy and society within a history an anomalous cooperation. Advances in Historical Studies 2: 185-193.

Castree N (2005) The epistemology of particulars: Human Geography, case studies, and "context". Geoforum 36(5):541-666

Crow-Miller B, Webber M and Molle F (2017) The (re)turn to infrastructure for water management? Water Alternatives 10(2): 195-207

Direção Nacional de Águas - DNA (1980) Plano Básico o Desenvolvimento Hidroagrícola do Vale do Incomáti. Maputo: BUREP.

Eriksen TH (2002) Ethnicity and Nationalism: Anthropological Perspectives. Second edition, London: Pluto Press.

Fantini E, Muluneh T and Smit H (2018) Big projects, strong states? Large scale investments in irrigation and state formation in the Beles valley, Ethiopia. In: Menga $F$ and Swyngedouw E (eds) Water, Technology and the Nation-State. London: Routledge Earthscan.

Foster R (2013) Tabula imperii europae: A cartographic approach to the current debate on the European Union as empire. Geopolitics 18(2): 371-402.

Friedmann J (1980) The territorial approach to rural development in the People's Republic of Mozambique: six discussion papers. International Journal of Urban and Regional Research 4(1): 97-111.

Furlong, K. 2015. Rethinking universality and disrepair: Seeking infrastrcture coexistence in Quibdò, Colombia. In Coutard, O. and Rutherford, J. (Eds), Beyond the networked city: Infrastructure reconfigurations and urban change in the North and South, pp. 94-113. New York: Routledge.

Hall M and Young T (1997) Confronting Leviathan: Mozambique since Independence. London: Hurst \& Company.

Harris L and Alatout S (2010) Negotiating hydro-scales, forging states: Comparison of the upper Tigris/Euphrates and Jordan River basins. Political Geography 29: 148-156.

Harris L (2012) State as socionatural effect: Variable and emergent geographies of the state in southeastern Turkey. Comparative Studies of South Asia, Africa and the Middle East 32(1): 25-39.

Isaacman AF and Isaacman B (2013) Dams, Displacement and the Delusion of Development. Cahora Bassa and its legacies in Mozambique (New African Histories), Athens: Ohio University Press.

Jenkins P (2000) City profile: Maputo. Cities 17(3): 207-218.

Kaika M (2006) Dams as symbols of modernization: The urbanization of nature between geographical imagination and materiality. Annals, Association of American Geographers 96(2): 276-301.

Kirchherr J (2018) Strategies of successful anti-dam movements: Evidence from Myanmar and Thailand. Society \& Natural Resources 31(2):166-182. 
Lefebvre H (1991) The Production of Space. Ofxord: Blackwell Publishing.

Linton J (2010) What is water? The History of a Modern Abstraction. Vancouver: UBC Press.

Linton J and Delay E (2018) Death by certainty: The Vinça dam, the French state, and the changing social relations of irrigation the Têt basin of the Eastern French Pyrénées. In: Menga $\mathrm{F}$ and Swyngedouw E (eds) Water, Technology and the Nation-State. London: Routledge Earthscan.

Macagno L (2009) Fragmentos de uma imaginação nacional. Revista Brasileira de Ciências Sociais 24(70): 17-35.

McCully P (1996) Silenced Rivers: The Ecology and Politics of Large Dams. London: Zed Books Ltd.

Meehan KM (2014) Tool-power: water infrastructures as wellsprings of state power, Geoforum 57: $215-224$.

Menga F (2015) Building a nation through a dam: the case of Rogun in Tajikistan. Nationalities Papers 43(3): 479-494.

Menga F and Swyngedouw E (2018) Water, Technology and the Nation-State. London: Routledge Earthscan.

Merme V, Ahlers R and Gupta J (2014) Private equity, public affair: hydropower financing in the Mekong Basin. Global Environmental Change 24: 20-29.

Ministério das Obras Públicas e Habitação - MOPH, Fundo de Investimento e Património do Abastecimento de Água - FIPAG (2011) Master Plan for the Greater Maputo Water Supply System. Master Plan Main Report. C. Lotti \& Associati S.p.A.; SIM S.p.A. GICO Branch.

Mirumachi N (2015) Transboundary water politics in the developing world. London and New York: Routledge.

Mitchell T (2002) Rule of Experts: Egypt, Techno-politics, Modernity. Berkeley: University of California Press.

Mitchell T (2006) Society, Economy and State Effect. In: Sharma A and Gupta A (eds.) The Anthropology of the State: a Reader. Oxford: Blackwell Publishing, pp. 169-187.

Molle F, Mollinga P and Wester P (2009) Hydraulic bureaucracies and the hydraulic mission: flows of water, flows of power. Water Alternatives 2(3): 328-49.

Moore D, Dore J, and Gyawali D (2010) The World Commission on Dams +10: Revisiting the large dam controversy. Water Alternatives 3(2): 3-13.

Neumann RP (1996) Nature-State-Territory: Toward a Critical Theorization of Conservation Enclosures. In: Peet $\mathrm{R}$ and Watts $\mathrm{M}$ (eds.) Liberation Ecologies: Environment, Development, Social Movements. London: Routledge.

Nusser M (2003) Political ecology of large dams: A critical review. Petermanns Geographische Mitteilungen 147: 20-27.

Painter J and Jeffrey A (2009) Political Geography: Second Edition. Los Angeles: Sage.

Painter J (2006) Prosaic geographies of stateness. Political Geography 25(7): 752-774.

Pitcher M (2006) Forgetting from above and memory from below: Strategies of legitimation and struggle in postsocialist Mozambique. Africa 76(1): 88-112. 
Power M. and Kirshner J. (2018), Powering the state: The political geographies of electrification in Mozambique, Environment and Planning C: Politics and Space, 0(0) 1-21

Radcliffe S (2001) Imagining the state as a space: Territoriality and the formation of the state in Ecuador. In: Hansen TB and Stepputat F (eds.) States of Imagination: Ethnographic Explorations of the Post-colonial State. Durham and London: Duke University Press, pp.123-149.

Robbins P (2008) The state in political ecology: A postcard to political geography from the field. In: Cox KR, Low M and Robinson J (eds.) The SAGE Handbook of Political Geography. London: SAGE, pp. 205-218.

Rodgers D and O'Neill B (2012) Infrastructural violence: introduction to the special issue. Ethnography 13(4): 401-12.

Rusca, M. (dir.) (2018). Water at the margins, Produced by Whales That Fly. Retrieved from

Rusca M. and Schwartz K., (2018) The Paradox of Cost Recovery in Heterogeneous Municipal Water Supply Systems: Ensuring Inclusiveness or Exacerbating Inequalities? Habitat International, Volume 73, Pages 101-108.

Sabaratnam M (2013) History repeating? Colonial, socialist and liberal statebuilding in Mozambique. In: Chandler D and Sisk T (eds.) The Routledge Handbook of International Statebuilding. London: Routledge, pp. 106-117.

Scott J (1999) Seeing like a State: How Certain Schemes to Improve the Human Condition have Failed. New Haven and London: Yale University Press.

Shapiro M (2003) Nation-states. In: Agnew J, Mitchell K and Toal G (eds.) A Companion to Political Geography. Oxford: Blackwell Publishing, pp. 271-289.

Shove, E. 2015. Infrastructures and practices: Networks beyond the city. In Coutard, O. and Rutherford, J. (Eds), Beyond the Networked City: Infrastructure reconfigurations and urban change in the North and South, pp. 242- 257. New York: Routledge.

Sidaway J (1992) Mozambique: Destabilization, state, society and space. Political Geography 11(3): 239-258.

Sidaway J (1993) Urban and Regional Planning in Post-independence Mozambique. International Journal of Urban and Regional Research 17(2): 241-59.

Simpson M (1993) Foreign and domestic factors in the transformation of Frelimo. The Journal of Modern African Studies 31(2): 309-37.

Sumich J (2010) Nationalism, urban poverty and identity in Maputo, Mozambique. Crisis States Research Centre - Working paper 68: Cities and Fragile States, London School of Economics.

Swyngedouw E (2004) Social Power and the Urbanisation of Water: Flows of Power. Oxford: Oxford University Press.

Swyngedouw E (2015) Liquid Power: Contested Hydro-modernities in Twentieth-century Spain. Cambridge: MIT Press. 
Tiwale, S.; Rusca, M. And Zwarteveen, M. 2018. The power of pipes: Mapping urban water inequities through the material properties of networked water infrastructures - The case of Lilongwe, Malawi. Water Alternatives 11(2): 314-335

UN-HABITAT (2016), World Cities Report 2016: Urbanization and Development - Emerging Futures, United Nations, New York, https://doi.org/10.18356/d201a997-en.

Wester P, Rap E and Vargas-Velázquez S (2009) The hydraulic mission and the Mexican hydrocracy: Regulating and reforming the flows of water and power. Water Alternatives 2(3): 395 - 415.

Wittfogel KA (1957) Oriental Despotism: A Comparative Study of Total Power. New Haven: Yale University Press.

World Bank (2007) Mozambique Country Water Resources Assistance Strategy: Making Water Work for Sustainable Growth and Poverty Reduction. Washington D.C.: The World Bank.

World Bank (2011) Project Appraisal Document on a Proposed Credit in the Amount of SDR 43.8 million to the Republic of Mozambique for the Water Resources Development Project. Washington D.C.: The World Bank.

World Bank (2013) Project Appraisal Document on a Proposed Credit in the Amount of SDR 118.8 million to the Republic of Mozambique for a Greater Maputo Water Supply Expansion Project. Washington D.C.: The World Bank.

World Bank (1987), Report and Recommendations of the President of the International Development association to the executive directors on a proposed IDA credit of SDR 54.5 million and a proposed a African Facility Credit of SDR 14.5 Million to the People's Republic of Mozambique for a second rehabilitation credit, Report No. P-4608-Moz. Washington D.C.: The World Bank.

World Commission on Dams (WCD) (2000). Dams and development: A new framework for decision-making. The Report of the World Commission on Dams. London and Sterling, VA: Earthscan.

Worster D (1985). Rivers of Empire: Water, Aridity, and the Growth of the American West. New York: Oxford University Press. 